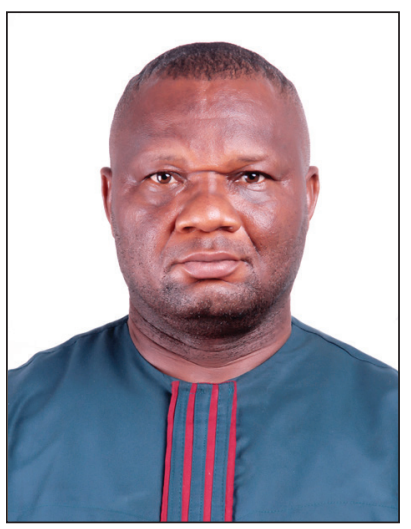

Nwocha Matthew Enya, PhD, Senior Lecturer and Head, Department of Jurisprudence and International Law, Faculty of Law, Ebonyi State University, Abakaliki, Nigeria email: nwochaenyaeni@gmail.com

\author{
doi: 10.21564/2414-990x.141.126349 \\ UDC 341.23(33)-025.31
}

\title{
CONSTRAINTS AND SOLUTIONS IN THE IMPLEMENTATION OF INTERNATIONAL ECONOMIC RIGHTS
}

This Paper It has discussed economic rights contained in the major international economic instruments, namely the International Covenant on Economic, Social and Cultural Rights; the Declaration on the Right to Development; and the African Charter on Human and Peoples' Rights. The Paper came against the background that there is need for nations, institutions and the international community to pay equal attention to economic and social rights as it does civil and political rights for in the final analysis, human rights are indivisible, inter-related and inter-dependent. The objective of this Paper, therefore, is to draw attention to this reality in order to reposition individuals and nations for economic prosperity and development. The Paper found among other things that the implementational mechanisms of these instruments are weak and ineffectual. It has also recommended amendments to the law and better strategies of implementation.

Keywords: economic rights; economic development; progressive implementation; recommendations of a general nature.

Нвоча Маттгев Ения, доктор философии, юридический факультет, Эбонийский государственный университет, Нигерия, г. Абакалики.

e-mail : nwochaenyaeni@gmail.com

Ограничения и решения при реализации международных экономических прав

Рассматриваются проблемь реализащии экономических прав, содержащихся в различных международных экономико-правовых документах, среди которых Международный пакт об экономических, сощиальных и культурных правах, Декларачия о праве на развитие, Африканская хартия прав человека и народов, существенно повлиявщие на развитие различных видов экономических прав. Указывается на существущие в документах противоречия, которые в сочетании со слабыми стратегиями реализации существенно ограничивают достижение поставленных целей. Сделано вывод, что странам, организачиям и всему международному сообществу необходимо уделять равное внимание экономическим и сочиальным правам, поскольку в конечном итоге они 
учитывают гражданские и политические права, а права человека неразделимы, взаимосвязаны и взаимозависимьь.

Ключевые слова: экономические права; экономическое развитие; прогрессивная реализация; рекомендации общего характера.

Introduction. According to Vasak, there are three generations of human rights. The first generation consists of civil and political rights such as the right to life, right to personal liberty, freedom of assembly, movement, speech, association, religion and conscience, right to fair hearing, right to private and family life and so forth. The second generation of human rights consists of economic, social and cultural rights such as the right to property, right to work, to just and favourable conditions of work, to join and form trade unions, to social security, to protection of and assistance to the family, to adequate standard of living, to education and to take part in the cultural life of the community. The third generation of human rights consists of collective rights which are enjoyed in group or collectively. They include the rights to development, self-determination, peace and security, to a general satisfactory environment, right to protection of cultural heritage and artifacts among others. The analysis contained in this Paper concentrates on the economic and development aspects of the so-called second and third generation of human rights. And this with a view to discovering, if not establishing, how the implementation of international economic rights particularly as contained in the International Covenant on Economic, Social and Cultural Rights, African Charter on Human and Peoples' Rights, and the Declaration on the Right to Development can impact on the economic prosperity of individuals and groups and by extension on the economic growth and development of nations.

International Economic Rights. The most significant treaty on international economic rights is the United Nations Covenant on Economic, Social and Cultural Rights. In the preamble to the Covenant, the High Contracting Parties recognize that the ideal of free human beings enjoying freedom from fear and want can only be achieved if conditions are created whereby everyone may enjoy his economic, social and cultural rights, among other things. By Article 1, all peoples have the right of self-determination which includes the right to freely determine their political status and pursue their economic, social and cultural development. In addition, all peoples may, for their own ends, freely dispose of their natural wealth and resources without prejudice to any obligations arising out of international economic co-operation based on the principle of mutual benefit and other principles of international law. Significantly, Article 1 also provides that in no case may a people be deprived of its own means of subsistence. Article 2 allows for a progressive realization of the rights contained in the covenant. In Article 3, States Parties undertake to ensure the equal right of men and women to the enjoyment of all economic, social and cultural rights provided for under the covenant. Article 4 places limitations on the enjoyment of the rights guaranteed subject to law made with the objective of promoting the general welfare of people in a democratic society. Article 5 forbids individuals, groups or the State from undertaking activities capable of derailing or 
destroying the rights guaranteed by the covenant. Article 6 secures the right to work including the right of everyone to the opportunity to gain his living by work which he freely chooses or accepts. The State Parties to the covenant are enjoined to take steps to achieve the full realization of this right including initiating technical and vocational guidance and training programmes, policies and techniques to achieve steady economic, and cultural development and full and productive employment under conditions safeguarding fundamental political and economic freedoms to the individual. Article 7 recognizes the right of everyone to the enjoyment of just and favourable conditions of work including fair wages and equal remuneration for work of equal value and decent living for workers and their families; safe and healthy working conditions; equal opportunity for everyone to be promoted in his employment to an appropriate higher level, subject to no considerations other than those of seniority and competence; rest, leisure, and reasonable limitation of working hours and periodic holidays with pay as well as remuneration for public holidays.

Article 8 secures the rights of everyone to form trade unions and join the trade union of his choice, subject only to the rules of the organization concerned, for the promotion and protection of his economic and social interests; the right of trade unions to establish national federations or confederations and the right of the later to form or join international trade union organizations; the right to strike, provided that it is exercised in conformity with the laws of the particular country. However, Article 8 (2) allows the imposition of lawful restriction on the exercise of the rights provided under Article 8 by members of the armed forces or of the police or of the administration of the State. Article 9 provides for the right of everyone to social security and social insurance. Article 10 protects family life, marriage, free consent of spouses and the education of children. It guarantees special protection to mothers during a reasonable period before and after childbirth. During such period, working mothers should be accorded paid leave or leave with adequate social security benefits. Special measures of protection and assistance should be taken on behalf of all children and young persons without any discrimination for reasons of percentage or other conditions. Children and young persons should be protected from economic and social exploitation. Their employment in work harmful to their moral or health or dangerous to life or likely to hamper their normal development should be punishable by law.

Article 11 proclaims the right of everyone to an adequate standard of living for himself and his family, including adequate food, clothing and housing and to the continuous improvement of living conditions. Everyone shall be free from hunger. Article 12 recognizes the right of everyone to the enjoyment of the highest attainable standard of physical and mental health. States Parties to the covenant shall take steps to achieve the full realization of this right including provisions for the reduction of the still-birth rate and of infant mortality and for the healthy development of the child, the improvement of all aspects of environmental and industrial hygiene; the prevention, treatment and control of epidemic, occupational and other diseases; the creation of conditions which would assure to him all medical services and medical attention in the event of sickness. 
Article 13 guarantees the right to education which shall be directed to the full development of the human personality and the sense of its dignity, and shall strengthen the respect for human rights and fundamental freedoms. In particular, primary education shall be compulsory and available free to all; secondary education in its different forms, including technical and vocational, shall be made generally available and accessible to all by every appropriate means, especially by the progressive introduction of free education; higher education shall be made equally accessible to all, on the basis of capacity, by every appropriate means, especially by the progressive introduction of free education; fundamental education shall be encouraged or identified as far as possible for those persons who have not received or completed the whole period of their primary education; the development of a system of schools at all levels shall be actively pursued, with adequate fellowship system established and the material conditions of teaching staff continuously improved. The liberty of parents and legal guardians, where applicable, to choose schools attended by their children is guaranteed. So also is the liberty of individuals and bodies to establish and direct educational institutions subject to the minimum standards laid down by the State. Article 14 enjoins States Parties to work out an action plan to implement compulsory primary education within specific timeline.

Article 15 secures the right of everyone to take part in cultural life; enjoy the benefit of scientific progress and is application; benefit from the protection of the moral and material interests resulting from any scientific, literary or artistic production of which he is the author. In this wise, States are mandated to take steps aimed at the full realization of these rights including those necessary for the conservation, development, and diffusion of science and culture. The State shall respect the freedom indispensable for scientific research and creative activity.

These provisions are indeed bountiful and ennobling. But there are other provisions in the covenant that pose direct challenge to the realization of the rights contained therein. Although Article 25 of the Covenant posits that nothing in the covenant shall be interpreted as impairing the inherent right of all peoples to enjoy and utilize fully and freely their natural wealth and resources, we hold the view that this absolute statement could have been a cheering one if the disposition of the natural wealth and resources had been or could be targeted at ameliorating the economic conditions of the people in general and empowering them to create wealth and a better life. Moreover, the self-contradictions in the covenant make its objectives more cumbersome to attain. Article 2(1) of the covenant provides that:

Each state party to the present covenant undertakes to take steps, individually and through international assistance and co-operation, especially economic and technical, to the maximum of its available resources, with a view to achieving progressively the full realization of the rights recognized in the present covenant by all appropriate means, including particularly the adoption of legislative measures.

The Committee on Economic, Social and Cultural Rights, a body established by the United Nations to supervise the implementation of the treaty has offered an interpretation of the above provision. In an analysis of Article 2(1), the committee 
admitted that the covenant provided for a progressive realization of the rights contained in the covenant and acknowledged the constraints due to limits of available resources. It however emphasized that, although the full realization of the relevant rights may be achieved progressively, steps towards that goal must be taken, within a reasonable time after the covenant's entry into force for the State concerned. The committee also re-iterated that a minimum core obligation to ensure the satisfaction of, at the very least, minimum essential levels of each of the rights is incumbent upon every State Party ${ }^{1}$. Whereas these comments express the frustration of the committee with the covenant, the simple interpretation in the final analysis, is that States are not compelled but encouraged to progressively make non-justiciable economic rights justiciable as their economies advanced to maturity. Umozurike has observed that it is apparent that in the circumstances, developing countries are free to determine to what extent they can guarantee the economic rights having regard to the human rights and the state of their economy². This situation obviously throws up a number of questions. What becomes of the rights guaranteed under the covenant while the economy makes its way to maturity? How long will it take to advance the economy? Are advanced economies always ready to grant economic rights to their citizens or implement the ones guaranteed under international law? Is there any hope of progressively enjoying economic rights in Africa, Latin America and other third world countries? To the first poser, the reality is that in the world of today a dominant number of nations are economically backward and that may well provide an escape or excuse for not implementing the rights guaranteed under the covenant. Secondly, even in advanced countries budget deficits, recession, increased spending on security and defence are always offered as excuses by governments for avoiding welfare policies or at best reducing them to the barest minimum. Most economic rights are welfarist in nature. Third, most economics move forth and back and in and out of recession and are known to have done so for generations of human life. It is, therefore, almost indefinite when such economies can stabilize and advance towards maturity. Fourth, third world nations present almost a hopeless case in this regard. Corruption, political instability, mismanagement, poor technological base, monocultural economies, weak legal and institutional structures, epileptic and unstable energy and power, and poor infrastructures are some of the factors that militate against economic advancement such that to speak of implementing the covenant under these circumstances appears not quite realistic.

There are also other areas in which constraints to the implementation of the covenant are visible. The most significant of them is the weak implementational procedure. By Article 16 of the covenant, the States Parties undertake to submit reports on the measures which they have adopted and the progress made in achieving the observance of the rights recognized under the covenant to the Secretary-

\footnotetext{
${ }^{1}$ K. Vasak (1979). "For the Third Generation of Human Rights: The Rights of Solidarity" Inaugural Lecture 10th Study Session of the International Institute of Human Rights, Strasbourg.

${ }^{2}$ Adopted and opened for signature, ratification and accession by the UN General Assembly Resolution 2200A (XXI) of 16 December, 1966; entered into force on 3rd January, 1976.
} 
General of the United Nations who thereafter transmits copies to the Economic and Social Council for consideration. The Secretary-General also transmits copies of the reports to relevant specialized agencies of the United Nations. By Article 19, the Economic and Social Council may transmit the reports, to the Commission on Human Rights for study and general recommendation. And the States Parties and specialized agencies may submit comments based on the general recommendations to the Economic and Social Council under Article 20. Then the Economic and Social Council may submit from time to time to the General Assembly reports with recommendations of a general nature and a summary of the information received from the States Parties and specialized agencies on the measures taken and the progress made in achieving the observance of the rights recognized under the covenant. By Article 22, the Economic and Social Council advises specialized agencies on international measures likely to contribute to the effective progressive implementation of the covenant. And under Article 23, the States Parties agree that international action for the achievement of the rights recognized in the covenant includes such methods as the conclusion of conventions, the adoption of recommendations, the furnishing of technical assistance and the holding of regional meetings and technical meetings for the purpose of consultation and study organized in conjunction with the Governments concerned.

From the implementation strategies presented above, it is clear that the covenant is more advisory than obligatory. Without any form of penalty or coercion, States are at liberty to present reports that suit them. These reports are never questioned neither is there any provision for any type of fact finding to confirm the accuracy of the reports. The reports are merely submitted for consideration by the Economic and Social Council and thereafter recommendations of a general nature are made to specialized agencies and States Parties concerned. By this weak and watery implementation procedure, only a government focused on the welfare of its citizens can implement the covenant even progressively. The implementation procedure has left a lot of loopholes that may be exploited by aberrant regimes to avoid the rights guaranteed under the covenant, and this is a huge constraint.

Recognizing these defects, the United Nations adopted an optional protocol to the covenant in 2008 ${ }^{1}$. The protocol empowers the Committee on Economic, Social and Cultural Rights to implement the rights guarantee under the covenant. However, the Committee shall not consider a communication unless it has ascertained that all available domestic remedies have been exhausted save where the application of such remedies is unreasonably prolonged ${ }^{2}$. Economic rights are not justiciable in most countries, a fact that both covenant and protocol did not speak to. Both do not provide a specific approach to be followed where this is the case and this is a huge omission. There are other weaknesses of the protocol. Not all States Parties to the covenant are parties to the protocol and the Committee can only receive and

\footnotetext{
${ }^{1}$ See General Comment No. 3 (1990): Report of the Committee on Economic, Social and Cultural Rights, Fifth Session, U.N DOC E/1991 23,E/C/2/1990/8, at 83 (1991)

${ }^{2}$ U.O Umozurike (2005) Introduction to International Law. Ibadan: Spectrum Books Ltd. Pg 146
} 
consider communications if it concerns States Parties to the protocol ${ }^{1}$. Even where it has considered a matter, the committee like the Economic and Social Council will end up with recommendations and advice ${ }^{2}$. By the nature of international politics where international institutions avoid criticism or aggressive behaviour, these recommendations and advice usually turn out to massage the political ego of offending States. Even more worrisome is that any State Party may denounce the protocol at any time by written notification addressed to the Secretary -General of the United Nations ${ }^{3}$. From the foregoing, it is clear that the implementation mechanism of the protocol is itself weak and unreliable. The International Covenant on Economic, Social and Cultural Rights is therefore left to float in uncharted waters in capable of being anchored by the beneficiaries, particularly the ordinary people who are the principal target of the treaty.

The African Charter on Human and Peoples' Rights, 1981, is a very comprehensive human rights instrument. It contains both civil and political rights; economic, social and cultural rights; and group or collective rights. But of concern to us here are the economic rights which it provides. Incidentally, economic rights contained in the charter are also part and parcel of collective rights since the charter does not guarantee economic rights to individuals as we have it under the International Covenant on Economic, Social and Cultural Rights. Article 21 provides thus:

All peoples shall freely dispose of their wealth and natural resources. This right shall be exercised in the exclusive interest of the people. In no case shall a people be deprived of it.

In case of spoliation the dispossessed people shall have the right to the lawful recovery of its property as well as to an adequate compensation.

Article 21(3), (4) and (5) caution that the disposition of such wealth and natural resources shall be exercised firstly without prejudice to the obligation of promoting international economic co-operation based on mutual respect, equitable exchange and the principles of international law; secondly, with a view to strengthening African unity and solidarity; and, thirdly, to eliminate all forms of foreign economic exploitation particularly that practiced by international monopolies so as to enable their peoples to fully benefit from the advantages derived from their national resources. In similar vein, Article 22 provides thus:

All peoples shall have the right to their economic, social and cultural development with due regard to their freedom and identity and in the equal enjoyment of the common heritage of mankind.

States shall have the duty, individually or collectively, to ensure the exercise of the right to development.

These provisions are welcome indeed especially against the background of, if not need for, African States to shake off the ubiquitous clutches of economic

\footnotetext{
${ }^{1}$ UN Resolution No. A/RES/63/117 of 10 December 2008, created the Optional Protocol to the International Covenant on Economic, Social and Cultural Rights.

${ }^{2}$ Article 3(1) of the Optional Protocol.

${ }^{3}$ Article 1 of the Optional Protocol.
} 
imperialism that has been the legacy of their past colonial domination. Multinational corporations domiciled in the home countries of former colonial masters are everywhere in Africa exploiting and manipulating their economies. This is in addition to international financial institutions founded and controlled by world powers that continue to offer conditional financial and developmental assistance to African Nations all geared towards maintaining control of their client nations. Article 21 and of the African Charter is therefore aimed in part at the economic emancipation of African nations so that their peoples can fully enjoy the benefits of their natural endowments and resources. As noble and salutary as these provisions may be, implementation of its contents with particular reference to economic rights still poses a huge obstacle. The mandate of the African Commission under Article 45 is weighted towards implementation of civil and political rights rather than economic rights. Again, Article 46(3) of the Protocol on the Statute of the African Court of Justice and Human Rights only provides that the States Parties undertake to comply with the judgment of the court in any case to which they are parties within the time stipulated by the court and to guarantee its execution. ${ }^{1}$ From the tone, spirit, and intendment of this article, there is a reasonable inference that what the charter has in contemplation is civil and political rights for the court cannot command the implementation of economic rights with time limits ex cathedra. Furthermore, Article 59 of the African Charter merely empowers the African Commission to publish its reports after it has been considered by the Assembly of Heads of State and Government and nothing more. Publication of the report does not compel obedience of the charter. Notwithstanding, Article 57 of the Protocol of the African Court mandates the court to submit to the Assembly of Heads of State and Government an annual report on its work during the previous year specifying in particular the cases in which a party has not complied with the judgment of the court. By Article 46(5) of the protocol, the Assembly may impose sanctions on the recalcitrant party. In practice, the report when submitted by the court to the Assembly may, in an atmosphere of mutual favour or otherwise conspiracy, be watered down if viewed as being too critical of a State Party. Secondly, the Assembly may decide within the law not to impose any sanctions and the matter ends there. From the foregoing analysis it is obvious that the legislative and institutional framework for the implementation of economic rights under the African charter is again weak and ineffectual.

The preamble to the United Nations Declaration on the Right to Development recognized that development is a comprehensive economic, social, cultural and political process which aims at the constant improvement of the wellbeing of the entire population and of all individuals on the basis of their active, free and meaningful participation in development and in the fair distribution of benefits resulting therefrom². It further recognized that the human person is the central

\footnotetext{
${ }^{1}$ The Protocol on the Statute of the African Court of Justice and Human Rights was adopted in 2008. It replaced the 1998 and 2003 Protocols and merged the African Court on Human and Peoples' Rights and the Court of Justice of the African Union.

${ }^{2}$ The Declaration on the Right to Development was adopted on 4th December, 1986, through UN Resolution No. UNGA \& A/RES/41/128. It has only 10 Articles.
} 
subject of the development process and that development policy should make the human being the main participant and beneficiary of development ${ }^{1}$. Article 1(1) provides thus:

The right to development is an inalienable human right by virtue of which every human person and all peoples are entitled to participate in, contribute to, and enjoy economic, social, cultural and political development, in which all human rights and fundamental freedoms can be fully realized.

The whole of Articles 1 to 8 enumerates various dimension of the right to development and the degrees of responsibility of the individual, groups and the State towards the achievement of the right to development. Article 8(1) instructively provides that:

States should undertake, at the national level, all necessary measures for the realization of the right to development and shall ensure, inter alia, equality of opportunity for all in their access to basic resources, education, health services, food, housing, employment and the fair distribution of income. Effective measures should be undertaken to ensure that women have an active role in the development process. Appropriate economic and social reforms should be carried out with a view to eradicating all social injustices.

In spite of the beautiful provisions of this declaration, it is clear that the rights contained therein are merely advisory, hortatory or inspirational. This view finds support in Article 10 which merely advises that steps should be taken to ensure the full exercise and progressive enhancement of the right to development, including the formulation, adoption and implementation of policy, legislative and other measures at the national and international levels. Aside of the general provision in Article 8(1) above, the declaration does not contain any specific implementation strategy neither does it contain any penalties for States that neglect or decline to implement its provisions. There is also nothing in the language of the declaration that creates any impression of mandatoriness. For these and other reasons, much of the hope that the declaration has raised concerning the economic right to development appears to fade away in practice. Notwithstanding these shortcomings, like the earlier Universal Declaration of Human Rights, the Declaration on the Right to Development has prepared a roadmap for nations and the international community alike to initiate binding legislative and other actions aimed at the realization of the right to development. It has also established standards of achievement and evaluation for nations, international as well as regional organizations and institutions to measure their progress in terms of human and economic development.

Recommendations. Admittedly, it is to the merit and credit of the International Covenant on Economic, Social and Cultural Rights that its provisions are to be applied or implemented by States Parties progressively. This is a realistic approach as it takes into account the disparities in the economic, social and institutional advancement as well as the national endowments of the various nations who are

\footnotetext{
${ }^{1}$ This is also the major plank of Article 2(1) to the effect that the human person is the central subject of development and should be the active participant and beneficiary of the right to development.
} 
States Parties. But this recognition is, again, potentially capable of pushing the argument into a slippery slope especially as in this case the instrument has not provided any measurable parameter on the level of economic maturity upon which the rights contained therein shall become mandatorily applicable. For the covenant to achieve its objectives there must be a standardized and verifiable criterion to measure the indices of economic maturity, progress and stability enough to require the mandatory implementation of the right guaranteed by the covenant. With regard to the reports submitted to the Secretary-General of the United Nations under Article 16, there is need to go beyond the mere recommendations of a general nature made by the Economic and Social Council. Both the Council and Committee created by the 2008 optional protocol should undertake fact-finding missions to verify and confirm the authenticity, or otherwise credibility, of the reports so submitted. And lastly, the optional protocol should be made applicable to all States Parties to the covenant. This is to enable the Committee work in synergy with the Council to secure a stronger impact in the monitoring and implementation of the covenant.

Furthermore, the mandate of the African Commission and that of the African Court of Justice and Human Rights must be strengthened to pay equal attention to economic and social rights as it does to civil and political rights. The African Charter rightly observed in its preamble that the States Parties are convinced that:

... it is henceforth essential to pay particular attention to the right to development and that civil and political rights cannot be dissociated from economic, social and cultural rights in their conception as well as universality and that the satisfaction of economic, social and cultural rights is a guarantee for the enjoyment of civil and political rights.

Both the African Commission and Court should act in tandem with the above observation. Again, African governments should cultivate the political will to impose effective sanctions under Article 46(5) in appropriate cases where a report of infringement has been brought by the Commission or the Court against an offending State Party.

Finally, the Declaration on the Right to Development should be formulated into an obligatory and binding international treaty. Its contents are a strong foundation for economic rights in international law and so if the groundswell for the international recognition of economic rights must have appropriate and relevant impact, concerted efforts must be made to clothe the declaration with a binding force. And the advice offered under Article 10 to the effect that steps should be taken to ensure the full exercise and progressive enhancement of the right to development through the formulation, adaptation of policy, legislative and other measures at the national and international levels must be urgently heeded.

Conclusion. Instruments on international economic rights exist both at the regional and international levels. The African Charter on Human and Peoples' Rights; the International Covenant on Economic, Social and Cultural Rights; and the Declaration on the Right to Development have all provided profusely for various classes of economic rights. But there are self-contradictions in the instruments that, 
coupled with weak implementational strategies, have constituted a huge constraint to the attainment of their set objectives. For the African Charter, there is need to strengthen the mandates of the African Court and the African Commission to pay equal attention to economic rights as they do civil and political rights. And African governments should develop the requisite political will that can impose effective sanctions on reneging and recalcitrant States Parties. The International Covenant on Economic, Social and Cultural Rights needs to be domesticated for its provisions to be effectively implemented among other things. The Declaration on the Right to Development needs to be formulated into a binding and obligatory instrument incorporating a workable and functional implementational strategy. When all these have been put in place economic rights shall receive the kind of boost that would result in economic prosperity for individuals, groups, and nations alike.

\section{Bibliography:}

1. General Comment No. 3. (1990): Report of the Committee on Economic, Social and Cultural Rights, Fifth Session, U.N DOC E/1991 23,E/C/2/1990/8, at 83 (1991).

2. Protocol on the Statute of the African Court of Justice and Human Rights, 2008.

3. Umozurike, U.O. (2005). Introduction to International Law. Ibadan: Spectrum Books Ltd.

4. Vasak, K. (1979). "For the Third Generation of Human Rights: The Rights of Solidarity" Inaugural Lecture $10^{\text {th }}$ Study Session of the International Institute of Human Rights, Strasbourg.

Нвоча Маттгев Енія, доктор філософії, юридичний факультет, Ебонійський державний університет, Нігерія, м. Абакалікі.

e-mail : nwochaenyaeni@gmail.com

\section{Обмеження і рішення у реалізації міжнародних економічних прав}

Розглянуто проблеми реалізації економічних прав, що містяться в різних міжнародних економіко-правових документах. Наголошено, що інструменти реалізащї міжнародних економічних прав існують як на регіональному, так і міжнародному рівнях, серед яких Міжнародний пакт про економічні, сочіальні і культурні права, Декларащія про право на розвиток, Африканська хартія прав людини і народів, які істотно вплинули на розвиток різних видів економічних прав на Африканському континенті. Окреслено певні суперечності, існуючі в цих документах, що поєднані зі слабкими стратегіями реалізащіі істотно обмежують можливість досягнення задекларованих $у$ них иілей. Зроблено висновок, що крайнам, організаціям $i$ всьому міжнародному співтовариству необхідно приділяти однакову увагу як економічним, так і сочіальним правам, оскільки в кінщевому підсумку вони враховують цивільні й політичні права, а права людини - нероздільні, взаємопов'язані й взаємозалежні. Таким чином мета статті - привернути увагу до існуючої реальності з метою підвищення якості та рівня життя людей, а також економічного процвітання $i$ розвитку цілих народів. Визначено слабкі та неефективні механізми реалізації цих нормативних актів, надано рекомендащії та поправки, а також запропоновано більш ефективні стратегії ї здійснення.

Ключові слова: економічні права; економічний розвиток; прогресивна реалізація; рекомендації загального характеру.

$$
\text { Надійшла до редколегї 19.03.2018 р. }
$$

